\title{
The impact of Fusarium ear rot in Poland and methods to reduce losses caused by the disease
}

\author{
Seweryn Frasiński ${ }^{1 凶}$, Elżbieta Czembor ${ }^{1}$, \\ Justyna Lalak-Kańczugowska²
}

\footnotetext{
${ }^{1}$ Instytut Hodowli i Aklimatyzacji Roślin — Państwowy Instytut Badawczy, Radzików Zakład Traw, Roślin Motylkowatych i Energetycznych Pracownia Traw Pastewnych i Roślin Motylkowatych,

${ }^{2}$ Instytut Genetyki Roślin, Polska Akademia Nauk, Poznań Zakład Genetyki Patogenów i Odporności Roślin,

$\bowtie$ e-mail: s.frasinski@ihar.edu.
}

\begin{abstract}
Maize has a significant economic impact all over the world. Fungi in the genus Fusarium that cause Fusarium ear rot (FER) of maize have significant effect on the yield quality and quantity. The main threat is the contamination of grain with the mycotoxins they produce - as these are harmful to humans and animals. Such mycotoxins are a group of secondary metabolites of varied structure, which belong mainly to trichothecenes, fumonisins and zearalenones. As no efficient chemical control read and pink rot in the field is possible, prevention relies on cultural practices and use resistant hybrids. Insects play an important role in the infection, which is why it is recommended to control their prevalence during growing season.
\end{abstract}

Keywords: Fusarium, Fusarium ear rot, mycotoxins, deoxynivalenol, fumonisins, zearalenone

Kukurydza ma istotne znaczenie ekonomiczne na całym świecie. Grzyby należące do rodzaju Fusarium powodujące fuzariozę kolb kukurydzy (FER) mają istotny wpływ na powstawanie strat jakościowych i ilościowych w plonie. Głównym zagrożeniem jest skażenie ziarna wytwarzanymi przez nie mykotoksynami, które są szkodliwe dla ludzi i zwierząt. Jest to grupa metabolitów wtórych, o zróżnicowanej budowie, należących głównie do trichotecenów, fumonizyn i zearalenonów. Z uwagi na fakt, że ochrona chemiczne jest mało efektywna, ważne jest stosowanie prawidłowej agrotechniki i dobór odpornej odmiany. Istotną rolę w zakażeniu odrywają żerujące na kukurydzy owady, stąd wskazane jest kontrolowanie ich występowania w uprawie.

Słowa kluczowe: Fusarium, fuzarioza kolb kukurydzy, mykotoksyny, deoksyniwalenol, fumonizyny, zearalenon,

\section{Introduction}

The importance of maize in Poland and worldwide

Maize play an important economic role and is often recognized as the 3 rd most cultivated crop in the world. It is growing both in the tropics (Africa and Central America) and in the moderate latitudes (FAOSTAT, 2020). It is used as a major and direct human food source, a raw material for processed food and as essential source of feed for farm animals, depending on the location (Ranum et al., 2014). The biofuel derived from maize also represents an important share of its use. It is included in the first generation of biofuels, with a low EROI index (Energy Returned on Energy Invested) that makes it on a so-called 'Net Energy Cliff', and the use of bioethanol in the context of reduction of $\mathrm{CO}_{2}$ emissions is criticised (Murphy et al., 2011; Brandt, 2017; IPCC AR5).

In Poland as well, there was a significant increase in the area of maize cultivation after 2010. The total cultivated area has surpassed 1 million ha (GUS 2020), of which about half of the crop is grain maize, exceeding 670 thousand ha in 2015 (GUS 2020; data for 2010-2017). Maize has a high yield per hectare, reaching an average value of $73.2 \mathrm{dt} / \mathrm{ha}$ for grain maize in Poland in 2013 (GUS 2020; data for 20102017).

The aim of this article is to summarise the state of knowledge in the world and to relate it to the situation in Poland. The article is also a summary of a speech from the conference "Dni Młodego Naukowca 2019" ("Young Scientist Days 2019"). 


\section{The importance of Fusarium ear rot in Poland and worldwide}

Fungi in the genus Fusarium causing fusarium red and pink ear rot have a significant impact on qualitative and quantitative yield losses. They causing many maize diseases at various stages of plants development such as seedling damping off, stalk rot of the adult plants or red and pink ear rot. Stalk rot is important because the plants are lodged and cannot be harvested. Fungi in the genus Fusarium that affect maize cobs produce secondary metabolites called mycotoxins which are harmful to humans and animals (Munkvold et al., 2019)

\section{Discolor section}

Individual Fusarium species are able to produce many different mycotoxins. Fusarium cumorum (W.G. Smith) Saccardo, which belong to Discolor section, causing red ear rot and produce mainly deoxynivalenol (DON). In chemical terms, it is a type B trichothecene (unlike type A trichothecenes, it has a ketone group in position C-8). It may also occur in two acetylated forms 3-AcDON and 15-AcDON and as double acetylated $3,15-\mathrm{AcDON}$, although this occurs in much smaller concentrations than other forms (Bottalico 1998; Leslie, Summerell, 2006). Fusarium graminearum Schwable chemotypes are more common on maize, most often producing 15-AcDON. In contrast, $3-A c D O N$ can be found mainly on wheat. However, their composition may vary and may be affected by weather conditions. The dangerous phenomenon is the presence in the plant material of DON-3-glucoside, called 'masked mycotoxin'. It is produced by plants as a defensive response and is not detectable by simple methods of DON testing, and can be converted back into a toxic form in the digestive tract. Little is known about masked mycotoxin bioactivity and this problem requires further research. (Berthiller et al., 2009; Berthiller et al., 2011; Galaverna et al., 2009). The Discolor section species also produce nivalenol (NIV), group B trichothecene which, despite being present in lower concentrations, is more toxic - having twice as low LD50 compared to DON (IARC, 1993). Moreover, these produce zearalenone (ZEA) - which is associated mainly with its ability to activate estrogen receptors and thus induce hormonal imbalance (Kowalska et al., 2016; Pasquali et al., 2016; Shier et al., 2001).

\section{Liseola section}

The Fusarium species of the Liseola section, causing pink fusariosis of cobs, produce other groups of toxins, the most important of which include FB1 and FB2 fumonisins (FUM). These are produced by Fusarium verticillioides (Saccardo) (Nirenberg), Fusarium temperatum Scaufl. \& Munaut and Fusarium profliferatum (Matsush.) Nirenberg (mainly FB1). Members of the Liseola section Fusarium subglutinans (Wollenw. \& Reinking), Fusarium poae (Peck) Wollenw. and F. proliferatum - are able to produce beauvercin (BEA) and moniliformin (MON). Apart from BEA and FUM, F. poae frequently colonizing maize grain, may occasionally produce T-2 toxin. T-2 toxin is produced in large quantities by Fusarium sporotrichioides Sherb., it's presence in Poland in silage has been confirmed, but it is not detected in maize grain (Panasiuk et al., 2019). T-2 and its deacetylated HT-2 derivative belong to type A trichothecenes and show relatively high toxicity (low LD50) (Logrieco et al., 2002; Leslie, Summerell, 2006; Miedaner et al., 2017).

\section{Fusarium mycotoxins}

A single species usually produces many types of mycotoxins, and different Fusarium species may co-exist on a single host. An additional risk is that contamination with Fusarium mycotoxins may occur despite the absence of any external signs or symptoms on the plants. All of them have a negative impact on animals and humans. For example, mentioned earlier DON, commonly found in plantand animal-based food, also known as vomitoxin, overcomes the blood-brain barrier. When it exceeds the safe level, it first causes a vomiting reaction, as well as a number of other complaints including dizziness, headaches and fever. Animal and in vitro tests have shown geno- and immunotoxic effects, effects on fertility, liver and kidney damage (Marasas, 2001; Missmer et al., 2006; Sobrova et al., 2010).

Toxins such as fumonisin B1 and B2 are classified by IARC in category B2 - probably carcinogenic to humans, while ZEA, DON and NIV still remain in category 3 (Ostry et al., 2017). For this reason, standards for acceptable concentrations have been established in many countries. In the European Union, the current regulations date back to 2006 (Commission Regulation (EC) No 1881/2006) with maximum levels specified for DON, ZEA, FB1, FB2. In 2013, Recommendation 2013/165/EU was made for T-2 and HT-2 with an advice for testing in case if the indicator level is exceeded, while the acceptable limits remain unset. There is still not enough data available, although the compounds seem to show high toxicity at low doses. For this reason, European Food Safety Authority 2017 
recommendations set the tolerable daily intake (TDI) for humans at $0.02 \mu \mathrm{g} / \mathrm{kg}$, where it is $1 \mu \mathrm{g} / \mathrm{kg}$ for DON, $2 \mu \mathrm{g} / \mathrm{kg}$ for fumonisins, NIV $0.7 \mu \mathrm{g} / \mathrm{kg}$, and $0.2 \mu \mathrm{g} / \mathrm{kg}$ for ZEA (Brera et al., 2008; Arcella et al., 2017).

\section{Fusarium on maize in Poland}

The species most commonly found on maize in Poland include F. graminearum, F. culmorum, F. poae, F. verticillioides, F. subglutinans, and $F$. temperatum. The occurrence of individual species has been changing over the years, however, the trend is towards a higher incidence of species associated with warmer regions, such as those from the Lisolea spp. section: $F$. verticillioides and $F$. temperatum, as compared to $F$. graminearum and $F$. poae which favour more temperate climate (Czembor et al., 2015; Gromadzka et al., 2019; Stępień et al., 2019). Therefore, also in Poland, a great deal of attention is paid to the monitoring of fungi populations of the genus Fusarium spp.

Using traditional and molecular methods, the IHAR-PIB (The Plant Breeding and Acclimatization Institute - National Research Institute) team identifies Fusarium species derived from maize grain of selected varieties grown in many locations (about 13 locations in 2015-2017, depending on the year). Initial findings from on-going unpublished study was presented at the conference "Dni Młodego Naukowca 2019”, where authors investigating effects of environmental conditions on the susceptibility of maize to FER and associated grain contamination with toxins. Following initial morphological evaluation, the obtained isolates are identified primarily with the molecular method, using species-specific primers based on SCAR markers (Mule et al., 2004; Scauflaire et. al., 2011; Czembor et. al., 2015). In case if there is no result obtained for the isolate, the identification is based on the tef- $1 \alpha$ factor sequencing - amplification with the EF728M and Tef1R primer pairs and reading of the sequence using Applied Biosystems devices (ABI Prism 3130XL) (Stępień et. al., 2012). The sequences are put together using the ClustalW and MEGA5 software (Thompson et. al., 2002; Tamura et. al., 2011). The species determination is performed through comparative analysis of the results with known sequences of individual Fusarium species from the GeneBank database.

Molecular identification of isolates shows statistically significant differences in the general species profile of the Fusarium genus. In general, F. verticillioides, whose secondary metabolites are fumonisins (FB1, FB2, FB3), has been the dominant species in the material collected over the last 3 years. In contrast, $F$. proliferatum, the second most common species in 2015 and 2017, was isolated only occasionally in 2016. Similarly, F. subglutinans isolated in larger quantities in 2016 , appeared incidentally or not at all in 2015 and 2017. Over the years, the constant presence of F. temperatum and $F$. graminearum draws the attention, as well. In addition, many isolates were identified as Fusarium avenaceum (Fr.) Sacc. in 2017, and $F$. poae - in 2015. The obtained results also indicate considerable diversification of the population of Fusarium strains depending on the morphology and earliness of the tested varieties at different locations in Poland, which may be dependent on the course of weather conditions (Frasiński et. al., 2019)

\section{Factors promoting the appearance of infec- tion}

For their propagation and survival in the environment, individual Fusarium spp. species use hardened hyphae, micro and macrospores, chlamydospores, and in the case of sexual reproduction ascospores (Munkvold et al., 1997). Residues of infested maize plants left in the field can be a source of primary infection for many years, also affecting other plants susceptible to these fungi as e.g. wheat (mainly F. graminearum) (Munkvold, 2003a). Although Fusarium species are mainly associated with the rhizosphere, in favourable conditions fungal spores can be transmitted by the wind for many kilometers (Munkvold, 2003b; Keller et al., 2014). Furthermore, there are reports of intercontinental transmissibility, e.g. with the Sahara dust (Palmero et al., 2011). Moreover, Fusarium can grow in alternative hosts such as weeds, fescue, soya, or sunflower cultures. Spore transmission vectors include plant feeding insects, such as the European corn borer (Ostrinia nubilalis) and corn beetle (Diabrotica virgifera) (Lew et al., 1996; Sobek, Munkvold, 1999; Munkvold, 2003b).

An important and well-described way of corn kernel infection by fungi belonging to the group Fusarium spp., especially $F$. graminearum, is the infection through the pistil of female inflorescences (cobs). Spores sprouting on their surface, transferred via wind or water from a neighbouring plants or from male inflorescences (panicles), can easily reach the kernels. A characteristic sign of this type of infection is the lightening that runs radially from kernel top (Thompson, Raizada, 2018). Another important route of infection is mechanical damage caused by insects, such as the corn borer, 
and this is particularly true for fungi from the Liseola section. Significant correlations have been proven between the occurrences of damage caused by the corn borer and disease intensity. This issue is discussed in many literature reports and own studies (Lew et al., 1991; Sobek, Munkvold, 1999; Munkvold, 2003b). In the case of $F$. verticillioides, the mechanism of systemic infection of the plant has also been ascertained; however, due to the short vegetation period and lower temperatures in Polish conditions, it requires experimental confirmation (Munkvold, Carlton, 1997; Murillo-Williams, Munkvold, 2008).

\section{Fusarium ear rot and climate change}

Observed climate changes and forecasts indicate changes in environmental conditions that result in a shift in range or the appearance of pathogens previously not observed in a given area. General forecasts for Poland can be found e.g. in the document "National Environmental Policy 2030" and are consistent with the current state of knowledge, presented in generally e.g. in Intergovernmental Panel on Climate Change reports (IPCC AR5). These reports show continuous increase of average air temperature with more frequent temperature extremes, uneven precipitation with extended periods without rain, growing water shortage areas, and decreasing ground water levels. Temperature changes favour corn crop culture (advantageous $\mathrm{WCI}$ ), while increasing the risk resulting from water deficit and shifting corn borer occurrence range to the north of the country (Uchwała nr 67 Rady Ministrów z dnia 16 lipca 2019 r.; Kundzewicz et al., 2017; Popkiewicz, Sierpińska, 2019). What is more, it is expected that sowing and harvesting will speed up by 16-21 days, depending on the greenhouse gas emission scenario (Piniewski et al., 2017).

Key climatic factors determining Fuasarium pathogens impact are, to a greater extent, temperature and humidity. Species differ in in optimum conditions they require. It was found, in general, $F$. graminearum is favoured by high moisture levels around silking and maturation period (Reid et al. 1999). F. verticillioides have been associated with warm and dry weather after milk stage (Munkvold et al., 2019). A shifts in pathogen geographic distribution has been observed in recent years for Fusari$u m$ species - a higher incidence of more thermophilic $F$. graminearum and the retreat of $F$. culmorum which prefers lower temperatures have been confirmed in the United Kingdom and Central and Northern Europe (Moretti et al., 2019). Currently, at the Plant Breeding and Acclimatization
Institute - National Research Institute (IHAR-PIB), research is carried out on the impact of weather and climatic conditions on the occurrence of individual Fusarium species on maize in Poland. Some of the results were also presented during the Conference "Dni Młodego Naukowca 2019" in Radzików IHAR, 7-8.11.2019.

\section{Corn protection methods}

The level of mycotoxins content, is influenced by a number of factors and interactions between them, such as genotype resistance, environmental conditions and the agrotechnology used. Weather conditions and the timing of infestation are important factors, as well. If the infection occurs at the end of the season and favourable conditions for mycelium development have occurred, the content of toxins in the grain may be low despite obvious morphological symptoms. On the other hand, high mycotoxin content at small mycelium reach may be caused by a situation wherein the infection occurs at the early kernel growth stage and then the development of mycelium is inhibited by unfavourable conditions (Herrera et al., 2010). Contamination with these compounds is also a risk factor after harvesting, and its main component is grain moisture. The risks in this case are posed in particular by $F$. verticillioides and $F$. proliferatum fumonisins, which have the capacity to grow and produce toxins with less water availability than other species (e.g. ZEA, F. graminearum producing DON and ZEA). Therefore, the harvested grain should be brought to a safe moisture level of $14 \%(0.70$ aw) as soon as possible (Marín et al., 2004; Magan, Aldred, 2007; Chulze, 2010).

The growing and using of resistant hybrid in cultivation is considered to be an economically reasonable and environmentally friendly method of protection against Fusarium diseases (Zijlstra et al., 2011; Czembor et al., 2018). There is no complete single gene resistance to infection. A number of studies have found different inheritance of resistance modes: additive, possibly non-additive effects, digenic (dominant) and polygenic patterns. Some genes have been found impacting silk resistance, but kernel resistance are under separate genetic control (Chungu et al., 1996). Studies reporting finding separate quantitive trait loci (QTL) for disease control in silk and kernel, but this approach is hard to incorporate into breeding programs. In this moment, breeders depend mainly on phenotyping system, as well investigating silk channel and kernel resistance, witch helps to eliminate very susceptible genotypes 
and grow moderately resistant hybrids. Breeders depends mainly on intraspecific genetic variability in search of more resistance levels, thus using more markers, improving phenotypic protocols and testing in multiple environments is way to go. (Robertson-Hoyt et al., 2007; Mestehazy et al., 2012, Lanubile et al., 2017, Munkvold et al. 2019). As the example, the different maize genotypes have different kernel morphologies, which affects susceptibility to Fusarium, in particular considering genotypes with grain of dent (Zea mays var. indentata) and flint (Zea mays var. indurata) types. The flint forms are characterised by hard outer endosperm layer, unlike the dent forms, where this layer does not cover the whole kernel and does not occur at its top (Hallauer, 2010, Wit et al., 2011). The level of resistance of individual varieties may be dependent on this (Czembor, Ochodzki, 2009). Silk way of Fusarium infection can be managed by selection for tighter husks, shorter silk emergence stage and faster silk abscission to reduce susceptibility period (Thomson et al., 2018).

Due to the route of infection, it is important to protect crops from insects, using both chemical and biological methods (the assessment of the efficiency of biological methods is carried out under Postęp Wieloletni 3.5 programe) (Munkvold, 2003a; Folcher et al., 2009). Less intensity of cob fusariosis and less accumulation of toxins is observed in the $B t$ maize varieties (Ostry et al., 2010). The use of fungicides is problematic and their effectiveness is limited to seed treatment, in order to protect against seedling damping off. Some prevention efficacy of spraying during the dusting phase, and later at the milky-wax phase boundary has been proven, but the method can be hardly justified economically because of the difficulty in assessing the risk of disease occurrence or its in tensification at the early phases (De Curtis et al., 2011).

Methods of protection against Fusarium diseases also include the use of proper agro-technical practices (Parsons, Munkvold, 2010). Balanced fertilization improves the resistance of the plants, especially during drought - positive effect of long-acting nitrogen fertilizers with the additive of potassium has been proven in the case of resistance to Fusarium ear rot. In addition, ensuring an optimal amount of nutrients during the vegetation period determines reduced accumulation of mycotoxins in the case of infestation. Furthermore, there is an evidence of less ear rot infections in stay-green varieties (Reid et al., 2001; Szulc et al., 2014; Bocianowski et al., 2016).

Post-harvest residues may be an important source of Fusarium pathogens, therefore, the plant succession and cultivation method play a very important role. It is recommended to schedule crops in such a way that the pathogens do not have constant access to the host, and it is not advised to continuously cultivate maize in monoculture. The same negative effect will be observed for direct succession of host plants (maize and cereals) or too short cycle between them (Mabuza et al., 2018; Munkvold, 2003a).

The correct technique for harvest residues is to mulch them. The use of ploughing to cover them is subject to discussion. Although the results of studies show greater infestation and mycotoxin accumulation in cereals and maize with residues left on fields, it is indicated that correct plant succession is more important. The advantage of less invasive cultivation methods, including the improvement of water retention, microbiome and nutrient availability in soil is that they can have positive effect on plant resistance and yield under difficult conditions. They also contribute to reduced use of raw materials and emissions from cultivation, although in this case yield is the decisive factor (Reid et al., 2001; Ferrigo et al., 2016; Król et al., 2018).

\section{Summary}

The risk assessment of maize cultivation and the prevention of adverse effects associated with Fusarium fungi is a complex issue that requires further research. This group of pathogens covers a broad spectrum of species differing inter alia in environmental preferences, which is of particular importance in the context of the climate changes. The risk assessment is problematic because phenotypic symptoms do not always reflect the content of harmful compounds produced by Fusarium. Due to species and intra-species variability (chemotypes), there is a need to test yields for a number of compounds, which complicates, prolongs and increases the cost of the quality control process. Therefore, it is crucial to know the composition of the Fusarium spp. populations in the country and the factors affecting it. Resistance of plants to the pathogen is a complex factor under multigenic control, which prolongs the process of creation of higher resistance varieties. Therefore, it is important to reduce the risk of the disease occurrence by using proper agrotechnology methods and controlling insect pests (mainly the corn borer), which are the vectors of the disease.

\section{Literature}

Arcella, D., Gergelova, P., Innocenti, M. L., Steinkell- 
ner, H. (2017). Human and animal dietary exposure to T-2 and HT-2 toxin. EFSA J. 15: doi:10.2903/j. efsa.2017.4972.

Berthiller, F., Dall'asta, C., Corradini, R., Marchelli, R., Sulyok, M., Krska, R., et al. (2009). Occurrence of deoxynivalenol and its 3- $\beta$-D-glucoside in wheat and maize. Food Addit. Contam. Part A 26: 507-511. doi:10.1080/02652030802555668.

Berthiller F., Krska R., Domig K. J., Kneifel W., Juge N., Schuhmacher R., Adam G. (2011). Hydrolytic fate of deoxynivalenol-3-glucoside during digestion. Toxicol Lett. Oct 30;206(3):264-7. doi: 10.1016/j.toxlet.2011.08.006.

Bocianowski, J., Szulc, P., Tratwal, A., Nowosad, K., Piesik, D. (2016). The influence of potassium to mineral fertilizers on the maize health. J. Integr. Agric. 15: 1286-1292. doi:10.1016/S2095-3119(15)61194-7.

Bottalico, A. (1998). Fusarium diseases of cereals: Species complex and related mycotoxin profiles, in Europe. Journal of Plant Pathology, 80(2), 85-103. https://doi. org/10.4454/jpp.v80i2.807

Brandt, A. R. (2017). How Does Energy Resource Depletion Affect Prosperity? Mathematics of a Minimum Energy Return on Investment (EROI). Biophys. Econ. Resour. Qual. 2: 2. doi:10.1007/s41247-017-0019-y.

Brera, C., De Santis, B., Debegnach, F., Miraglia, M. (2008). "Mycotoxins," in Food contaminants and residue analysis. Comprehensive analytical chemistry. volumne 51 Food Science Text Series., ed. Y. Piko (Oxford: Elsevier), 582.

Chungu. C., Mather, D.E., Reid, L.M., Hamilton, R.I. (1996) Comparison of techniques for inoculating maize silk, kernel, and cob tissues with Fusarium graminearum. Plant Dis $80: 81-84$

Chulze, S. N. (2010). Strategies to reduce mycotoxin levels in maize during storage: a review. Food Addit. Contam. Part A 27: 651-657. doi:10.1080/19440040903573032.

Commission Recommendation 2013/165/EU of 27 March 2013 on the presence of T-2 and HT-2 toxin in cereals and cereal products: http://data.europa.eu/eli/reco/2013/165/oj [Accessed: 12.11.2020]

Commission Regulation (EC) No 1881/2006 of 19 December 2006 setting maximum levels for certain contaminants in foodstuffs: http://data.europa.eu/eli/reg/2006/1881/oj [Accessed: 12.11.2020]

Czembor, E., Frasiński, S., Elżbieta, C., Seweryn, F. (2018). Polskie elitarne linie wsobne kukurydzy źródłem odporności na fuzariozę kolb (Fusarium spp.) i głownię guzowatą (Ustilago maydis). Prog. Plant Prot. 58: 22-27. doi:10.14199/ppp-2018-002.

Czembor, E., Ochodzki, P. (2009). Resistance of flint and dent maize forms for colonization by Fusarium spp. and mycotoxins contamination. Maydica 54: 263-267.

Czembor, E., Stępień, Ł., Waśkiewicz, A. (2015). Effect of Environmental Factors on Fusarium Species and Asso- ciated Mycotoxins in Maize Grain Grown in Poland. PLoS One 10: e0133644. doi:10.1371/journal.pone.0133644.

De Curtis, F., De Cicco, V., Haidukowski, M., Pascale, M., Somma, S., Moretti, A. (2011). Effects of agrochemical treatments on the occurrence of Fusarium ear rot and fumonisin contamination of maize in Southern Italy. F. Crop. Res. 123: 161-169. doi:10.1016/j.fcr.2011.05.012.

FAOSTAT (2020). Statistical Division of the UN Food and Agriculture Organization. http://www.fao.org/faostat [Accesed: 12.11.2020]

Genebank NIH genetic sequence database. https://www.ncbi. nlm.nih.gov/genbank [Accesed: 12.11.2020]

Ferrigo, D., Raiola, A., Causin, R. (2016). Fusarium Toxins in Cereals: Occurrence, Legislation, Factors Promoting the Appearance and Their Management. Molecules 21: 627. doi:10.3390/molecules21050627.

Folcher, L., Jarry, M., Weissenberger, A., Gérault, F., Eychenne, N., Delos, M., et al. (2009). Comparative activity of agrochemical treatments on mycotoxin levels with regard to corn borers and Fusarium mycoflora in maize (Zea mays L.) fields. Crop Prot. 28: 302-308. doi:10.1016/j. cropro.2008.11.007.

Frasiński, S., Czembor E., Lalak-Kańczugowska, J. (2019) Czynniki środowiskowe modyfikujące porażenie odmian kukurydzy pastewnej grzybami z rodzaju Fusarium spp. Dni Młodego Naukowca 2019, Radzików IHAR, 7-8.11.2019

Galaverna G., DallAsta C., Mangia M., Dossena A., Marchelli R. (2009): Masked Mycotoxins: an Emerging Issue for Food Safety. Czech J. Food Sci., 27: S89-S92.

Gromadzka, K., Błaszczyk, L., Chełkowski, J., Waśkiewicz, A. (2019). Occurrence of mycotoxigenic fusarium species and competitive fungi on preharvest maize ear rot in Poland. Toxins (Basel). 11:. doi:10.3390/ toxins11040224.

GUS (2020) Rocznik Statystyczny Rolnictwa 2019, Warszawa: 140, 141, 149.

Herrera, M., Conchello, P., Juan, T., Estopañan, G., Herrera, A., Ariño, A. (2010). Fumonisins concentrations in maize as affected by physico-chemical, environmental and agronomical conditions. Maydica 55: 121-126.

Intergovernmental Panel on Climate Change (IPCC) (2017) IPCC Fifth Assessment Report (AR5) Observed Climate Change Impacts Database, Version 2.01. Palisades, NY: NASA Socioeconomic Data and Applications Center (SEDAC). https://doi.org/10.7927/H4FT8J0X [Accessed: 12.11.2020]

Keller, M. D., Bergstrom, G. C., Shields, E. J. (2014). The aerobiology of Fusarium graminearum. Aerobiologia (Bologna). 30: 123-136. doi:10.1007/s10453-013-9321-3.

Kowalska K., Habrowska-Górczyńska D. E., Piastowska-Ciesielska A. W. (2016) Zearalenone as an endocrine disruptor in humans. Environ Toxicol Pharmacol. Dec;48:141-149. doi: 10.1016/j.etap.2016.10.015. Epub 
2016 Oct 18. PMID: 27771507.

Król, A., Żyłowski, T., Kozyra, J., Księżak, J. (2018). Soil moisture under no-tillage and tillage systems in maize long-term experiment. Polish J. Soil Sci. 51: 103-117. doi:10.17951/pjss/2018.51.1.103.

Kundzewicz, Z. W., Hov, Ø., Okruszko, T. (2017). Zmiany klimatu i ich wpływ na wybrane sektory w Polsce. ISRL PAN Poznań: CHASE-PL.

Leslie, J. F., Summerell, B. A. (2006). The Fusarium Laboratory Manual., eds. J. F. Leslie and B. A. Summerell Ames, Iowa, USA: Blackwell Publishing doi:10.1002/9780470278376.

Lew, H., Adler, A., Edinger, W. (1991). Moniliformin and the European Corn Borer (Ostrinia nubilalis). Mycotoxin Res. 7: 71-76. doi:10.1007/BF03192189.

Lew, H., Chelkowski, J., Pronczuk, P., Edinger, W. (1996). Occurrence of the mycotoxin moniliformin in maize (Zea mays L.) ears infected by Fusarium subglutinans (Wollenw. \& Reinking) Nelson et al. Food Addit. Contam. 13: 321-324. doi:10.1080/02652039609374414.

Logrieco, A., Mulè, G., Moretti, A., Bottalico, A. (2002). Toxigenic Fusarium species and mycotoxins associated with maize ear rot in Europe. Eur. J. Plant Pathol. 108: 597-609. doi:10.1023/A:1020679029993.

Magan, N., Aldred, D. (2007). Post-harvest control strategies: Minimizing mycotoxins in the food chain. Int. J. Food Microbiol. 119: 131-139. doi:10.1016/j.ijfoodmicro.2007.07.034.

Mabuza, L.M., Janse van Rensburg, B., Flett, B.C. et al. (2018) Accumulation of toxigenic Fusarium species and Stenocarpella maydis in maize grain grown under different cropping systems. Eur J Plant Pathol 152, 297-308. https://doi.org/10.1007/s10658-018-1475-y

Marasas, W. F. (2001). Discovery and occurrence of the fumonisins: a historical perspective. Environ. Health Perspect. 109 Suppl: 239-43. doi:Doi 10.2307/3435014.

Marín, S., Magan, N., Ramos, A. J., Sanchis, V. (2004). Fumonisin-producing strains of Fusarium: a review of their ecophysiology. J. Food Prot. 67: 1792-805. doi:10.4315/0362-028X-67.8.1792.

Mesterházy, A. K., Lemmens, M., Reid, L. (2012). Breeding for resistance to ear rots caused by Fusarium spp. in maize - a review. Plant Breeding. 131. 1-19.

Miedaner, T., Gwiazdowska, D., Waśkiewicz, A. (2017). Editorial: Management of Fusarium Species and their Mycotoxins in Cereal Food and Feed. Front. Microbiol. 8: 1-3. doi:10.3389/fmicb.2017.01543.

Missmer, S. A., Suarez, L., Felkner, M., Wang, E., Merrill, A. H., Rothman, K. J., et al. (2006). Exposure to Fumonisins and the Occurrence of Neural Tube Defects along the Texas-Mexico Border. Environ. Health Perspect. 114: 237-241. doi:10.1289/ehp.8221.

Moretti, A., Pascale, M., Logrieco, A. F. (2019). Mycotoxin risks under a climate change scenario in Europe.
Trends Food Sci. Technol. 84: 38-40. doi:10.1016/j. tifs.2018.03.008.

Munkvold, G. P. (2003)a. Cultural and genetic approaches to managing mycotoxins in maize. Annu. Rev. Phytopathol. 41: 99-116. doi:10.1146/annurev. phyto.41.052002.095510.

Munkvold, G. P. (2003)b. Epidemiology of Fusarium diseases and their mycotoxins in maize ears. Eur. J. Plant Pathol. 109: 705-713. doi:10.1023/A:1026078324268.

Munkvold, G. P., Arias, S., Taschl, I., and Gruber-Dorninger, C. (2019). "Mycotoxins in corn: occurrence, impacts, and management," in Corn Chemistry and Technology, ed. S. O. Serna-Saldivar (Cambridge: Woodhead Publishing), 235-287.

Munkvold, G. P., Carlton, W. M. (1997). Influence of Inoculation Method on Systemic Fusarium moniliforme Infection of Maize Plants Grown from Infected Seeds. Plant Dis. 81: 211-216. doi:10.1094/PDIS.1997.81.2.211.

Munkvold, G. P., McGee, D. C., Carlton, W. M. (1997). Importance of Different Pathways for Maize Kernel Infection by Fusarium moniliforme. Phytopathology 87: 209-217. doi:10.1094/PHYTO.1997.87.2.209.

Murillo-Williams, A., Munkvold, G. P. (2008). Systemic Infection by Fusarium verticillioides in Maize Plants Grown Under Three Temperature Regimes. Plant Dis. 92: 1695-1700. doi:10.1094/PDIS-92-12-1695.

Murphy, D. J., Hall, C. A. S., Powers, B. (2011). New perspectives on the energy return on (energy) investment (EROI) of corn ethanol. Environ. Dev. Sustain. 13: 179-202. doi:10.1007/s10668-010-9255-7.

Mulè, G., Susca, A., Stea, G., Moretti, A. (2004) A species-specific PCR assay based on the calmodulin partial gene for identification of Fusarium verticillioides, $F$. proliferatum and F. subglutinans. Eur J Plant Pathol: 110: 495-502.

Ostry, V., Malir, F., Toman, J., Grosse, Y. (2017). Mycotoxins as human carcinogens - the IARC Monographs classification. Mycotoxin Res. 33: 65-73. doi:10.1007/s12550016-0265-7.

Ostry, V., Ovesna, J., Skarkova, J., Pouchova, V., Ruprich, J. (2010). A review on comparative data concerning Fusarium mycotoxins in $\mathrm{Bt}$ maize and non- $\mathrm{Bt}$ isogenic maize. Mycotoxin Res. 26: 141-145. doi:10.1007/s12550-0100056-5.

Palmero, D., Rodríguez, J. M., De Cara, M., Camacho, F., Iglesias, C., Tello, J. C. (2011). Fungal microbiota from rain water and pathogenicity of Fusarium species isolated from atmospheric dust and rainfall dust. J. Ind. Microbiol. Biotechnol. 38: 13-20. doi:10.1007/s10295-010-0831-5.

Panasiuk, L., Jedziniak, P., Pietruszka, K., Piatkowska, M., Bocian, L. (2019). Frequency and levels of regulated and emerging mycotoxins in silage in Poland. Mycotoxin Res. 35: 17-25. doi:10.1007/s12550-018-0327-0.

Parsons, M. W., Munkvold, G. P. (2010). Associations of plant- 
ing date, drought stress, and insects with Fusarium ear rot and fumonisin B1 contamination in California maize. Food Addit. Contam. Part A. Chem. Anal. Control. Expo. Risk Assess. 27: 591-607. doi:10.1080/19440040903456337.

Pasquali, M., Beyer, M., Logrieco, A., Audenaert, K., Balmas, V., Basler, R., et al. (2016). A European database of Fusarium graminearum and F. culmorum trichothecene genotypes. Front. Microbiol. 7:. doi:10.3389/ fmicb.2016.00406.

Piniewski, M., Szczęśniak, M., Marcinkowski, P., O’Keeffe, J., Okruszko, T., Nieróbca, A., et al. (2017). "Projekcje wpływu zmian klimatu na rośliny jare do roku 2050 w oparciu o symulacje modelu," in Zmiany klimatu i ich wpływ na wybrane sektory w Polsce, eds. Z. Kundzewicz, Ø. Hov, and T. Okruszko (Poznań: ISRL PAN Poznań), 182-198.

Popkiewicz, M., Sierpińska, A. (2019). Konsekwencje zmiany klimatu dla Polski wg Ministerstwa Środowiska. Available at: https://naukaoklimacie.pl/aktualnosci/ konsekwencje-zmiany-klimatu-dla-polski-wg-ministerstwa-srodowiska-311 [Accessed: 15.01.2020].

Ranum, P., Peña-Rosas, J. P., Garcia-Casal, M. N. (2014). Global maize production, utilization, and consumption. Ann. N. Y. Acad. Sci. 1312: 105-112. doi:10.1111/ nyas. 12396.

Reid, L., Nicol, R., Ouellet, T., Savard, M., Miller, J., Young, J., Stewart, D., Schaafsma, A. (1999) Interaction of Fusarium graminearum and F. mon- iliforme in maize ears: disease progress, fungal biomass, and mycotoxin accumulation. Phytopathology 89 (11), 1028-1037.

Reid, L. M., Zhu, X., Ma, B. L. (2001). Crop rotation and nitrogen effects on maize susceptibility to gibberella (Fusarium graminearum) ear rot. Plant Soil 237: 1-14. doi:10.1023/A:1013311703454.

Scauflaire, J., Gourgue, M., Munaut, F. (2011) Fusarium temperatum sp. nov. from maize, an emergent species closely related to Fusarium subglutinans. Mycologia 103: 586-597. pmid:21186324

Shier W.T., Shier A.C., Xie W., Mirocha C.J. (2001) Structure-activity relationships for human estrogenic activity in zearalenone mycotoxins. Toxicon. Sep;39(9): 1435-8. doi: 10.1016/s0041-0101(00)00259-2.

Sobek, E. A., Munkvold, G. P. (1999). European Corn Borer (Lepidoptera: Pyralidae) Larvae as Vectors of Fusarium moniliforme, Causing Kernel Rot and Symptomless Infection of Maize Kernels. J. Econ. Entomol. 92: 503-509. doi:10.1093/jee/92.3.503.

Sobrova, P., Adam, V., Vasatkova, A., Beklova, M., Zeman, L., Kizek, R. (2010). Deoxynivalenol and its toxicity. Interdiscip. Toxicol. 3: 94-99. doi:10.2478/v10102-0100019-x.

Stępień, Ł., Gromadzka, K., Chełkowski, J. (2012) Polymorphism of mycotoxin biosynthetic genes among Fusarium equiseti isolates from Italy and Poland. J Appl Genet; 53: 227-236. pmid:22354659

Stępień, Ł., Gromadzka, K., Chełkowski, J., Basińska-Barczak, A., Lalak-Kańczugowska, J. (2019). Diversity and mycotoxin production by Fusarium temperatum and Fusarium subglutinans as causal agents of pre-harvest Fusarium maize ear rot in Poland. J. Appl. Genet. 60: 113-121. doi:10.1007/s13353-018-0478-x.

Szulc, P., Rybus-Zajac, M., Jagla, M. (2014). Influence of nitrogen dose, type of nitrogen fertilizer and method of its application on plant health of maize hybrids (Zea mays L.). Electron. J. Polish Agric. Univ. Ser. Agron. 17

Tamura, K., Peterson, D., Peterson, N., Stecher, G., Nei, M., Kumar, S. (2011) MEGA5: Molecular evolutionarygenetics analysis using maximum likelihood, evolutionary distance, and maximum parsimony methods.Mol. Biol. Evol. 28: 2731-2739

Thompson, J.D.; Gibson, T.J.; Higgins, D.G. (2002) Multiple Sequence Alignment Using ClustalW and ClustalX.Curr. Protoc. Bioinform. 00: 2.3.1-2.3.2

Thompson, M., Raizada, M. (2018). Fungal Pathogens of Maize Gaining Free Passage Along the Silk Road. Pathogens 7: 81. doi:10.3390/pathogens7040081.

Uchwała nr 67 Rady Ministrów z dnia 16 lipca 2019 r. w sprawie przyjęcia „Polityki ekologicznej państwa 2030 - strategii rozwoju w obszarze środowiska i gospodarki wodnej”. (2019) Monitor Polski 2019: poz 794. http:// www.monitorpolski.gov.pl/mp/2019/794/1] [Accessed: 16.01.2020].

Wit, M., Warzecha, R., Mirzwa-Mróz, E., Jabońska, E., Ochodzki, P., Waśkiewicz, A., et al. (2011). Susceptibility of flint and dent maize ears to Fusarium species. Phytopathologia:, 35-45.

Zijlstra, C., Lund, I., Justesen, A. F., Nicolaisen, M., Jensen, P. K., Bianciotto, V., et al. (2011). Combining novel monitoring tools and precision application technologies for integrated high-tech crop protection in the future (a discussion document). Pest Manag. Sci. 67: 616-625. doi:10.1002/ps.2134.

Sponsorzy Dni Młodego Naukowca:

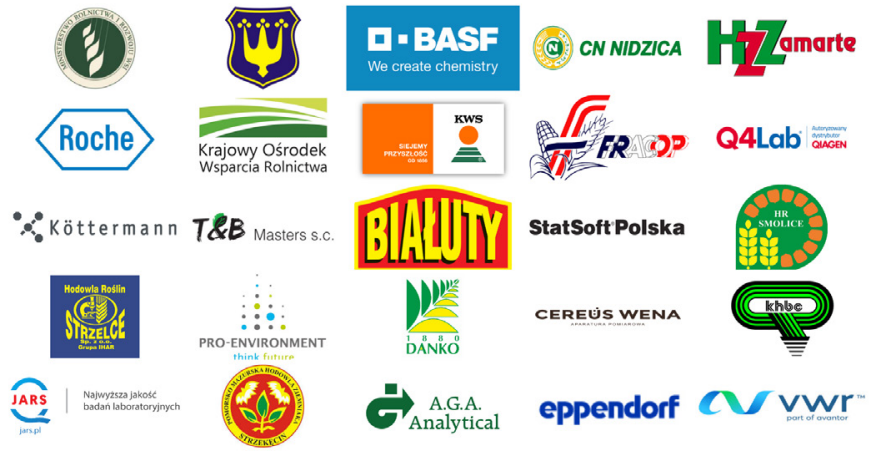

